\title{
Anticonvulsant evaluation of Rauvolfia ligustrina Willd. ex Roem. \& Schult., Apocynaceae, in rodents
}

\author{
Lucindo J. Quintans-Júnior, ${ }^{* 1}$ Jullyana S. Siqueira, ${ }^{2}$ Mônica S. Melo, ${ }^{1}$ Davi A. Silva, ${ }^{2}$ \\ Liana C. S. L. Morais, ${ }^{2}$ Maria de Fátima V. Souza, ${ }^{2}$ Reinaldo N. Almeida ${ }^{2}$
}

\author{
${ }^{1}$ Departamento de Fisiologia. Universidade Federal de Sergipe. Campus Universitário "Prof. Aloísio de Campos", \\ 49100-000 São Cristóvão-SE, Brazil \\ ${ }^{2}$ Laboratório de Tecnologia Farmacêutica, Universidade Federal da Paraíba, Caixa Postal 5009, 58051-970 \\ Paraíba-PB, Brazil.
}

\begin{abstract}
RESUMO: “Avaliação anticonvulsivante de Rauvolfia ligustrina Willd. ex Roem. \& Schult., Apocynaceae, em roedores". O presente estudo buscou avaliar os efeitos do extrato etanólico das raízes de Rauvolfia ligustrina Willd. ex Roem. \& Schult., Apocynaceae, (EER) e sua possível atividade anticonvulsivante em roedores. No teste das convulsões induzidas pelo pentilenotetrazol (PTZ) os animais tratados com EER, $250 \mathrm{mg} / \mathrm{kg}$ (i.p.), apresentaram aumento significativo $(p<0,05)$ da latência para o aparecimento das convulsões $(328,9 \pm 47,5)$ quando comparado aos do grupo controle $(103,5 \pm 21,8)$ e reduziu o número de óbitos. Esse efeito foi bloqueado pela administração do flumazenil. O EER produziu aumento significativo $(p<0,05)$ na latência nos testes da picrotoxina (PIC) e da estricnina (EST), nas maiores doses. No modelo do eletrochoque auricular o EER não produziu alterações significativas em nenhum dos parâmetros avaliados. Entretanto, no modelo do abrasamento induzido pelo PTZ, a administração com o EER produziu um efeito protetor, atenuando de forma significativa $(p<0,05)$ o desenvolvimento e a severidade das crises convulsivas. Os resultados, sugerem que o EER induziu efeito anticonvulsivante em roedores e que o sistema GABAérgico pode estar envolvido nessa resposta.
\end{abstract}

Unitermos: Rauvolfia ligustrina, pentilenotetrazol, picrotoxina, abrasamento, flumazenil.

\begin{abstract}
The Aim of this study was to evaluated the effects of the ethanol extract of Rauvolfia ligustrina Willd. ex Roem. \& Schult., Apocynaceae, roots (EER) in animal models of epilepsy. The EER increased the latency for convulsions significantly different from control $(p<0,05)$ and in the PTZ induced convulsions test on $62,5 \mathrm{mg} / \mathrm{kg}$ (i.p.) decreased mortality. This effect was blocked by flumazenil administration, suggesting an involvement of GABAergic system in the anticonvulsant activity of EER. The EER had a moderate effect only against PIC- or STR-induced convulsions at doses 125 and $250 \mathrm{mg} / \mathrm{kg}$. But in the MES test it did not demonstrate effect on this animal model. Therefore, the EER reduced the development of PTZ-induced kindling in both experimental groups. It also significantly $(p<0.05)$ decreased the latency for convulsions and reduced its percentage. Our results suggest that EER owns anticonvulsant property.
\end{abstract}

Keywords: Rauvolfia ligustrina, pentylenetetrazole, picrotoxin, kindling, flumazenil.

\section{INTRODUCTION}

Epilepsy is a major neurological disorder and up to $4 \%$ of the world population develops epilepsy in their lifetime. A substantial number, approximately $20-30 \%$, of epileptic patients continue to have seizures in spite of adequate treatment with antiepileptic drugs (AEDs) (Jeub et al., 2002). Traditional systems of medicine are popular in developing countries and up to $80 \%$ of the population relies on traditional medicines or folks remedies for primary health care needs (Akerele, 1988). A great number of scientists and organizations turn their attention to traditional therapies in order to find and conserve important resources. However, the medicinal plants have been an important source of new drugs with biological activity (Carlini, 2003).

Rauvolfia ligustrina Willd. ex Roem. \& Schult., Apocynaceae, is a plant found in Latin America, popularly known as "arrebenta-boi" (Moura \& Agra, 1989). The study with other species of Rauvolfia has demonstrated that it possesses depressant activity in the Central Nervous System (CNS) (Woodson et al., 1957; Madawala et al., 1994). However, folk medicine practitioners in the Brazilian Northeast use the infusion of the aerial parts for the treatment of neurological disorders, as anxiety (oral communication). A preliminary behavioral 
screening developed in our laboratory has showed that the ethanol extract of $R$. ligustrina roots (EER) has depressants effects on the CNS (Quintans-Júnior et al., 2000). Recent investigation provided evidence of the possible anticonvulsant effect of total alkaloids fraction of $R$. ligustrina (TAF) in two animal models of epilepsy (Quintans-Júnior et al., 2007; 2008). Therefore, the purpose of this study consisted of investigating the effects of the EER in animal models of epilepsy.

\section{MATERIAL AND METHODS}

\section{General}

The drugs used were: diazepam (DZP), pentylenetetrazole (PTZ), picrotoxin (PIC), phenytoin (PHE), polyoxyethylene-sorbitan monolated (Tween 80), cremophor were purchased from Sigma (USA) and diazepam (DZP) from Cristalia (Brazil). Agents were administrated by intraperitoneally (i.p.) or orally route (p.o.) at a dose volume of $0,1 \mathrm{~mL} / 100 \mathrm{~g}$.

\section{Plant and Extract}

Roots of Rauvolfia ligustrina Willd. ex Roem. \& Schult., Apocynaceae, were collected from Santa Rita, Brazil and identified by Dr MF Agra. A voucher specimen (M F Agra 5594 JPB, LTF) has been deposited in the herbarium of the Laboratório de Tecnologia Farmacêutica (LTF), Universidade Federal da Paraíba. The roots were oven-dried at $40{ }^{\circ} \mathrm{C}$ and pulverized an extracted in a room of temperature with $95 \%$ ethanol in water for $72 \mathrm{~h}$. The extract was dried at $60{ }^{\circ} \mathrm{C}$ using rotavapor and the yield was approximately of $20 \%$ for obtaining the ethanol extract of R. ligustrina roots (EER).

\section{Animals}

Male Wistar rats (200-250 g) and Swiss mice (25$30 \mathrm{~g}$ ), with 2-3 months of age, were used throughout this study. The animals were randomly housed in appropriate cages at $25 \pm 1^{\circ} \mathrm{C}$ on a $12 \mathrm{~h}$ light/dark cycle (lights on 06:0018:00) with free access to food (Purina) and water. They were used in groups of ten animals each. Experimental protocols and procedures were approved by the Laboratório de tecnologia farmacêutica animal care and use committee (CEPA/LTF/UFPB No1105/06).

\section{Acute toxicity}

Different doses of EER were administered intraperitonally (i.p.) $(100,200,400,600,800$ and 1000 $\mathrm{mg} / \mathrm{kg}$ ), while the control group received only the vehicle. The groups were observed for $48 \mathrm{~h}$ and at the end of this period mortality was recorded for each group (Dietrich, 1983).

\section{PTZ-induced convulsions}

PTZ (60 mg/kg i.p.) was used to induce clonic convulsions (Smith et al., 2007). Mice were divided into five groups $(\mathrm{n}=10)$, the first group served as control and received Tween $80(0.2 \%)$ with one drop of cremophor, while the second group was treated with diazepam (DZP, $2 \mathrm{mg} / \mathrm{kg}$, i.p.). The remaining groups received an injection of EER $(62.5 ; 125$ and $250 \mathrm{mg} / \mathrm{kg}$, i.p.). After $60 \mathrm{~min}$ of drug administration, the mice were treated with PTZ (i.p.) at a dose of $60 \mathrm{mg} / \mathrm{kg}$. The latency and percent of clonic convulsions were registered. The incidence of deaths was noted until $48 \mathrm{~h}$ after the injection of PTZ.

\section{Effects of flumazenil on PTZ-induced convulsion}

The effect of selective GABAA-BZD receptor antagonist, flumazenil (File \& Pellow, 1986), on the anticonvulsant activity of EER was investigated. In the experimental groups, mice were given flumazenil (FLU) $(10 \mathrm{mg} / \mathrm{kg}$, i.p.) $20 \mathrm{~min}$ before the administration of EER $(125$ and $250 \mathrm{mg} / \mathrm{kg}$ ) (60 min before the injection of PTZ). In the standard group, the animals received FLU 20 min before the administration of diazepam $(2 \mathrm{mg} / \mathrm{kg}$, i.p. $)$ (60 min before the injection of PTZ). The anticonvulsant activity of EER and diazepam in mice pretreated with FLU was assessed.

\section{PIC-induced convulsion}

The detailed method has been previously described (Smith et al., 2007). Animals were divided into five groups $(n=10)$, the first group served as control and received Tween $80(0.2 \%)$ with one drop of cremophor, while the second group was treated with diazepam (DZP, 2 $\mathrm{mg} / \mathrm{kg}$ i.p.). The remaining groups received an injection of EER $(62.5,125$ and $250 \mathrm{mg} / \mathrm{kg}$, i.p.). After $60 \mathrm{~min}$ of drug administration, the mice were treated with PIC at a dose of $8 \mathrm{mg} / \mathrm{kg}$ (i.p.). Immediately after the injection of the convulsant drug, mice were individually placed in plastic boxes and observed for the time onset of clonic seizures (latency), percent of clonic convulsions and deaths. The incidence of deaths was noted until $48 \mathrm{~h}$ after the injection of PIC. Diazepam at $2 \mathrm{mg} / \mathrm{kg}$ (i.p.) was used as positive control.

\section{Maximal electroshock test}

MES produces reproducible tonic convulsions characterized by tonic hindlimb extension (THE) (Oliveira et al., 2001). In this experiment, electroconvulsive shock $(130 \mathrm{~V}, 150$ pulses/s, $0.5 \mathrm{~s})$ was delivered through auricular electrodes (ECT UNIT 7801-Ugo Basile) to induced THE. Mice were divided into five groups $(\mathrm{n}=10)$, the first group served as control and received Tween $80(0.2 \%)$ with one drop of cremophor, while the second group was treated 
with phenytoin (PHE, $25 \mathrm{mg} / \mathrm{kg}$, i.p.). The others groups received an injection of EER, similarly before experiment. After 60 min all groups received electroconvulsive shock. The animals that did not exhibit THE were considered protected (Tortoriello \& Ortega, 1993).

\section{Chemical kindling}

Forty male Wistar rats were randomly distributed into four groups, consisting of ten animals each $(\mathrm{n}=10)$. The first group served as control and received the vehicle, Tween $80(0.2 \%)$ with one drop of cremophor, while the second group was treated with phenytoin (PHE, $35 \mathrm{mg}$ / $\mathrm{kg}$; i.p.). The remaining groups received an injection of EER at doses of $62.5 \mathrm{mg} / \mathrm{kg}$ (i.p.) and $250 \mathrm{mg} / \mathrm{kg}$ (p.o.). Experimental and PHE groups received administrations once daily.

To induce kindling the animals were injected with $25 \mathrm{mg} / \mathrm{kg}$ (i.p.) PTZ twice daily for 13 days (Kondziella et al., 2002). After each administration of PTZ, latency of clonic convulsions and percent inhibition were observed for $15 \mathrm{~min}$ for each animal. The convulsions intensities were classified as described by Schröeder et al. (1999), with modifications: stage 0: no response; stage 1: convulsive waves though the body; stage 2: myoclonic jerks, rearing; stage 3: clonic convulsions; stage 4: generalized tonicclonic convulsions. The administrations of PTZ were carried out at 8:00 and 16:00.

\section{Statistical analysis}

The data obtained were evaluated by one-way analysis of variance (ANOVA) followed by Dunnett's t test. The incidence (\%) of clonic or tonic-clonic convulsions as well as the mortality were evaluated by Fisher's Test. Twofactor repeated-measures analysis of variance (ANOVA) of seizures development was performed followed by Tukey`s post hoc test. Differences were considered to be statistically significant when $p<0.05$.

\section{RESULTS}

\section{Acute Toxicity}

The $\mathrm{LD}_{50}$ by i.p. route of the EER was measured by $680.4(584.6-776.2) \mathrm{mg} / \mathrm{kg}$.

\section{Effect of EER on PTZ induced convulsions and treatment with flumazenil}

Table 1 shows that in the control group the PTZ consistently induced clonic convulsions in $100 \%$ of mice. On the other hand, the EER did not affect the clonic convulsions at the tested dose. However, the administration of $62.5 \mathrm{mg} / \mathrm{kg}$, i.p. of EER increased the latency of clonic convulsions significantly different from control $(p<0.05$;
Dunnett's test), similarly occurs with group received $125 \mathrm{mg} / \mathrm{kg}$, i.p. of EER. The pretreatment with DZP significantly prolonged the latencies and blocked effective clonic convulsions induced by PTZ.

On the other hand, in PTZ-induced convulsions model, the administration of FLU (10 mg/kg, i.p.) antagonized the effect of EER in the prolongation of convulsion latency. There was no significant difference between the latency of convulsions in mice received EER (125 and $250 \mathrm{mg} / \mathrm{kg}$, i.p.) pretreated with FLU and the control group. FLU significantly antagonized the anticonvulsant activity of diazepam (Table 1).

Table 1. Effect of EER on PTZ-induced seizures in mice.

\begin{tabular}{lcccc}
\hline Treatment & $\begin{array}{c}\text { Dose } \\
(\mathrm{mg} / \mathrm{kg})\end{array}$ & ${\text { Latency }(\mathrm{s})^{\mathrm{a}}}^{\%}$ & $\begin{array}{c}\% \\
\text { Seizures }\end{array}$ & $\%$ Death \\
\hline Control & - & $103.5 \pm 21.8$ & 100 & 70 \\
EER & 62.5 & $299.2 \pm 68.0^{\mathrm{d}}$ & $80 \mathrm{~b}$ & $30^{\mathrm{c}}$ \\
EER & 125 & $248.9 \pm 60.3^{\mathrm{d}}$ & $70 \mathrm{~b}$ & $40^{\mathrm{b}}$ \\
EER & 250 & $328.9 \pm 47.5^{\mathrm{d}}$ & $70 \mathrm{~b}$ & $50^{\mathrm{b}}$ \\
EER + FLU & $125+10$ & $141.8+38.9$ & 100 & 60 \\
EER + FLU & $250+10$ & $139.0+52.1$ & 100 & 100 \\
DZP & 2 & $739.5 \pm 29.7^{\mathrm{e}}$ & $10 \mathrm{c}$ & $0^{\mathrm{c}}$ \\
DZP + FLU & $2+10$ & $133.3+24.4$ & 100 & 70 \\
\hline
\end{tabular}

$n=10$

${ }^{a}$ Values represent mean \pm S.D.

${ }^{\mathrm{b}} p<0.05$ (Fisher's test), significantly different from control.

${ }^{c} p<0.01$ (Fisher's test), significantly different from control.

${ }^{\mathrm{d}} p<0.05$ (one-way ANOVA and Dunnett's test), significantly different from control.

e $p<0.01$ (one-way ANOVA and Dunnett's test), significantly different from control.

\section{Effect of the EER on PIC-induced convulsions}

As shown in the Table 2, the EER at doses of $62.5,125$ and $250 \mathrm{mg} / \mathrm{kg}$ increased the latency of clonic convulsions significantly different from control $(p<0.05)$ against convulsions induced by PIC.

Table 2. Effect of the EER on PIC-induced seizures in mice.

\begin{tabular}{lcccc}
\hline Treatment & $\begin{array}{c}\text { Dose } \\
(\mathrm{mg} / \mathrm{kg})\end{array}$ & ${\text { Latency }(\mathrm{s})^{\mathrm{a}}}^{\%}$ & $\begin{array}{c}\% \\
\text { Seizures }\end{array}$ & \% Death \\
\hline Control & - & $406.6 \pm 12.6$ & 100 & 70 \\
EER & 62.5 & $582.7 \pm 37.2^{\mathrm{d}}$ & 90 & 70 \\
EER & 125 & $529.1 \pm 15.2^{\mathrm{d}}$ & $70^{\mathrm{b}}$ & $30^{\mathrm{b}}$ \\
EER & 250 & $561.9 \pm 57.3^{\mathrm{d}}$ & $60^{\mathrm{b}}$ & $30^{\mathrm{b}}$ \\
DZP & 2 & $1079.2 \pm 81.9^{\mathrm{e}}$ & $10^{\mathrm{c}}$ & $0^{\mathrm{c}}$ \\
\hline
\end{tabular}

$n=10$

${ }^{a}$ Values represent mean \pm S.D.

${ }^{\mathrm{b}} p<0.05$ (Fisher's test), significantly different from control. ${ }^{c} p<0.01$ (Fisher's test), significantly different from control. 
${ }^{\mathrm{d}} p<0.05$ (one-way ANOVA and Dunnett's test), significantly different from control.

${ }^{\mathrm{e}} p<0.01$ (one-way ANOVA and Dunnett's test), significantly different from control.

\section{Effect on MES induced convulsions}

The results of MES induced seizures are shown in Table 4. In the group treated with all doses of EER did not inhibit tonic hindlimb seizures and did not affect in lethality. On the other hand, the PHE decreased significantly both: tonic hindlimb seizures and lethality $(p<0.01$; Fisher`s test $)$.

Table 3. Effect of EER on MES induced tonic seizures in mice.

\begin{tabular}{lccc}
\hline Treatment & $\begin{array}{c}\text { Dose } \\
(\mathrm{mg} / \mathrm{kg})\end{array}$ & $\begin{array}{c}\text { \% tonic hindlimb } \\
\text { seizures }^{\mathrm{a}}\end{array}$ & \% Death \\
\hline Control & - & 100 & 90 \\
EER & 62.5 & 100 & 100 \\
EER & 125 & 100 & 90 \\
EER & 250 & 100 & 100 \\
PHE & 25 & $10^{\mathrm{b}}$ & $0^{\mathrm{b}}$ \\
\hline
\end{tabular}

$n=10$

${ }^{\text {a }}$ Values represent mean \pm S.D.

${ }^{\mathrm{b}} p<0.01$ (Fisher`s test), significantly different from control.

\section{Effect of EER on PTZ-kindling}

The development of PTZ-induced kindling is shown in Figure 1. After three days of PTZ-injection a stage three convulsions was reached in the control group, whereas the experimental group $(62.5 \mathrm{mg} / \mathrm{kg}$, i.p.; 250 $\mathrm{mg} / \mathrm{kg}$, p.o.) did not surpass stage 2 until 8th day. The PHE group significantly decreased the development of convulsions in comparison with the control group.

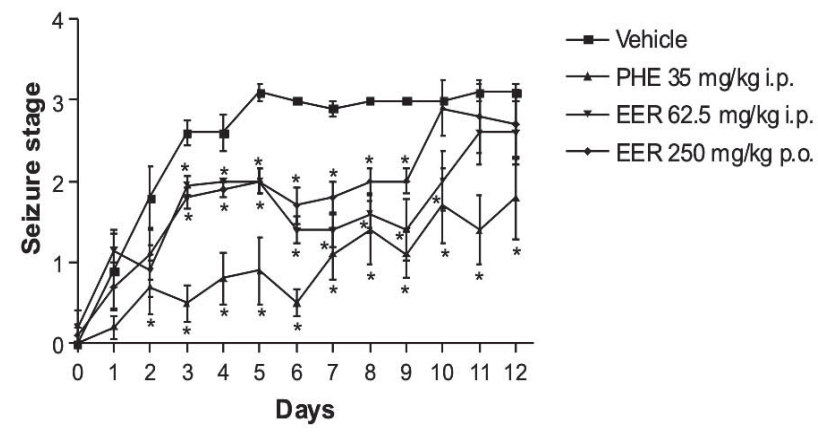

Figure 1. Kindling development induced by daily administration of PTZ (35 mg/kg, i.p.). Two-factor repeated-measures analysis of variance (ANOVA) was performed followed by Tukey`s post hoc test. Data repressed in mean $\pm \mathrm{SEM},{ }^{*} p<0.05 ; \mathrm{n}=10$
Table 4. Effect of EER on PTZ-kindling in rats.

\begin{tabular}{lcccc}
\hline Treatment & $\begin{array}{c}\text { Dose } \\
(\mathrm{mg} / \mathrm{kg})\end{array}$ & Route & Latency $(\mathrm{s})^{\mathrm{a}}$ & $\begin{array}{c}\text { \% inhibition } \\
\text { of seizures }\end{array}$ \\
\hline Vehicle & - & i.p. & $169.3 \pm 18.3$ & 0 \\
PHE & 25 & i.p. & $715.5 \pm 45.2^{\mathrm{e}}$ & $90^{\mathrm{c}}$ \\
EER & 62,5 & i.p. & $420.2 \pm 90.7^{\mathrm{d}}$ & $50^{\mathrm{b}}$ \\
EER & 250 & p.o. & $422.4 \pm 67.5^{\mathrm{d}}$ & $60^{\mathrm{b}}$ \\
\hline
\end{tabular}

$n=10$

a Values expressed in mean \pm S.D.

${ }^{\mathrm{b}} p<0.05$ (Fisher's test), significantly different from control.

${ }^{c} p<0.01$ (Fisher's test), significantly different from control.

d $p<0.05$ (one-way ANOVA and Dunnett's test), significantly different from control.

${ }^{\mathrm{e}} p<0.01$ (one-way ANOVA and Dunnett's test), significantly different from control.

Table 5 shows that PTZ consistently induced clonic convulsions in $100 \%$ of control mice. On the other hand, the EER at both doses significantly increased $(p<0.05$; Dunnett's test) the latency of the onset clonic convulsions as compared to the control group and inhibited the convulsions at both doses in 50\%. However, the administration of PHE $35 \mathrm{mg} / \mathrm{kg}$ significantly increased ( $p<0.01$; Dunnett`s test) the latency of the clonic convulsions onset and inhibited the convulsions in $90 \%(p<0.01$; Fisher`s test $)$.

\section{DISCUSSION}

The main goal of this study was to evaluate the possible anticonvulsant effect of the EER in rodents. Our results demonstrated that acute administration with EER (62.5 and $125 \mathrm{mg} / \mathrm{kg}$, i.p.) on PTZ, PIC and PTZ-kindling tests promoted an increase in the latency to convulsions significantly different from control $(p<0.05$ or $p<0.01)$, also showing protective effect.

PTZ is considered as an experimental model for the "generalized absence convulsions". It produces clonic and tonic convulsions when administrated parenterally (Smith et al., 2007). PTZ may cause convulsions by inhibiting chloride ion channels associated with GABAA receptors (Löscher \& Schmidt, 2006). Drugs to promote absence convulsion or increased of the latency in PTZinduced seizures are suggest anticonvulsant activity (Haruna, 2000). Benzodiazepines and many barbiturates act promote an increase of the inhibition synaptic interact for GABA, reducing the excitability neuronal and increase threshold convulsions (Löscher \& Schmidt, 2006). Therefore, PIC has been shown to interact with the GABA neurotransmitter and the GABA receptor complex (Löscher, 1998). However, antagonism of PTZ- and PICinduced convulsions suggests that the EER might have effects on GABAergic neurotransmission.

In order to determine the role of BZD receptors participation in the EER-induced anticonvulsant 
effects, flumazenil (FLU), a specific antagonist of the benzodiazepine site in the GABAA-BZD receptor complex (File \& Pellow, 1986), was used. The results obtained from PTZ-induced convulsion model in mice pretreated with FLU suggest that EER could facilitate the inhibitory activity of the GABAergic system probably through a competitive agonist action in the BZD site of the GABA receptors.

In contrast, MES test is the most frequently used as an animal model for identification of anticonvulsant activity of drugs for the "grand mal" (Oliveira et al., 2001; Smith et al., 2007). All the currently available AEDs, wich are clinically effective in the treatment of generalized tonicclonic convulsions (PHE), phenobarbital, lamotrigine and carbamazepine are effective in the MES test (Löscher, 1998). Absence anticonvulsant activities in the MES test suggest that EER do not possess effect on this animal model, in doses tests.

The kindling has become the most studied animal model of epilepsy and it is characterized by an increased susceptibility to convulsions after repeated application of initially subconvulsive chemical stimuli (Mason \& Cooper, 1972). The mechanism underlying kindling are nowadays still not completely understood (Rössler et al., 2000). However, PTZ has been shown to interact with the GABA neurotransmitter and the GABA receptor complex (Löscher \& Schmidt, 2006). On the other hand, investigations concerning the biochemistry of glutamate, especially modifications in glutamate binding after electrical kindling, showed increased glutamate release and increased receptor density in target neurons populations (Cincotta et al., 1991). Other studies provided evidence that AMPA and NMDA receptors are involved in the initiation of convulsions and their propagation, and that NMDA receptors antagonists retard the development of kindling (Becker et al., 2001). Although, little is known about the changes of the glutamatergic neuronal transmission after chemical kindling induced by repeated applications of initially subconvulsive doses of PTZ (Rauca et al., 2000), however, alteration in glutamatergic system may not be the main factor but one of several possibilities.

Summarizing our data, the results suggest a possible anticonvulsant effect of EER in rodents. The precise mechanisms of possible anticonvulsant effect of EER are not clear, however, GABAergic and glutamatergic neurotransmitter system might be involved. Nevertheless, more studies will be required for elucidation this effect and neuronal mechanisms relationship.

\section{ACKNOWLEDGEMENTS}

We thank Dr. M.F. Agra of the Botany section for collection and identification of plant to this material. This work was supported by "Conselho Nacional de Desenvolvimento Científico e Tecnológico (CNPq/ Brazil)" and "Fundação de Apoio à Pesquisa e à Inovação
Tecnológica do Estado de Sergipe (FAPITEC/SE)”.

\section{REFERENCES}

Akerele O 1988. Medicinal plants and primary health care: an agenda for action. Fitoterapia 59: 355-363.

Becker A, Grecksch G, Schröeder H 2001. Low doses of AMPA exert anticonvulsant effects on pentylenetetrazol-kindled seizures. Pharmacol Biochem Be 70: 421-426.

Carlini EA 2003. Plants and the central nervous system. Pharmacol Biochem Be 75: 501-512.

Cincotta M, Young NA, Beart PM 1991. Unilateral up-regulation of glutamate receptors in limbic regions of amygdaloidkindled rats. Exp Brain Res 85: 650-658.

Dietrich L 1983. A new approach to practical acute toxicity testing. Arch Toxicol 54: 275-287.

File SE, Pellow S 1986. Intrinsic actions of the benzodiazepine receptor antagonist Ro 15-1788. Psychopharmacology 88: 1-11.

Haruna AK 2000. Depressant and anticonvulsant properties of the root decoction of Afrormosia laxiflora (Leguminosae). Phytother Res 14: 57-59.

Jeub M, Beck H, Siep E, Rüschenschmidt C, Speckmann EJ, Ebert U, Potschka H, Freichel C, Reissmüller E, Löscher W 2002. Effect of phenytoin on sodium and calcium currents in hippocampal CA1 neurons of phenytoinresistant kindled rats. Neuropharmacology 42: 107-116.

Kondziella D, Bidar A, Urfjell B, Sletvold O, Sonnewald U 2002. The pentylenetetrazole-kindling model of epilepsy in SAMP8 mice: behavior and metabolism. Neurochem Int 40: 413-418.

Löscher W 1998. New visions in the pharmacology of anticonvulsion. Eur J Pharmacol 342: 1-13.

Löscher W, Schmidt D 2006. New horizons in the development of antiepileptic drugs: Innovative strategies. Epilepsy Res 69: 183-272.

Madawala PG, Arambewela LSR, Premakumarab GAS, Ratnasooriab WD 1994. Studies on the sedative activity of crude extract of root bark of Rauvolfia canescens on rats. J Ethnopharmacol 42: 63-65.

Mason CR, Cooper RM 1972. A permanent change in convulsive threshold in normal and brain-damaged rats with repeated small doses of pentylenotetrazol. Epilepsia 13: 663-674.

Moura MDB, Agra MF 1989. Apocynaceae tóxicas e medicinais ocorrentes nos estados de Pernambuco e Paraíba. Acta Bot Bras Anais do XL Congresso Nacional Botânica 3: 273-279.

Oliveira FA, Almeida RN, Sousa MFV, Barbosa-Filho JM, Diniz SA, Medeiros IA 2001. Anticonvulsant properties of $\mathrm{N}$-salicyloyltryptamine in mice. Pharmacol Biochem Be 68: 199-202.

Quintans-Júnior LJ, Diniz SA, Diniz RST, Almeida RN, Barbosa-Filho JM 2000. Avaliação da toxicidade aguda e da atividade psicofarmacológica dos extratos etanólicos brutos das partes aéreas e raízes de Rauvolfia ligustrina. XVI Simpósio de Plantas Medicinais do Brasil. Recife- 
PE, Brasil 1: 261.

Quintans-Júnior LJ, Silva DA, Siqueira JS, Souza MFV, Barbosa-Filho JM, Almeida RN, Silva Júnior RGC 2007. Anticonvulsant properties of the total alkaloid fraction of Rauvolfia ligustrina Roem. et Schult. in male mice. Rev Bras Farmacogn 17: 152-158.

Quintans-Júnior LJ, Almeida JRGS, Lima JT, Nunes XP, Siqueira JS, Oliveira LEG, Almeida RN, Athayde-Filho PF, Barbosa-Filho JM 2008. Plants with anticonsvulsant properties-a review. Rev Bras Farmacogn 18: 798-819.

Rauca C, Pohle W, Grunenberg K, Franze S 2000. Hypothermia inhibits pentylenetetrazol kindling and prevents kindlinginduced deficit in shuttle-box avoidance. Pharmacol Biochem Be 65: 23-30.

Rössler AS, Schröeder H, Dodd RH, Chapouthier G, Grecksch G 2000. Benzodiazepine receptor inverse agonist-induced kindling of rats alters learning and glutamate binding. Pharmacol Biochem Be 67: 169-175.

Schröeder H, Becker A, Schröeder U, Hoellt V 1999. ${ }^{3} \mathrm{H}-$ L-Glutamate binding and ${ }^{3} \mathrm{H}-\mathrm{D}$-Aspartate release from hippocampal tissue during the development of pentylenetetrazole kindling in rats. Pharmacol Biochem Be 62: 349-352.

Smith M, Wilcox KS, White HS 2007. Discovery of antiepileptic drugs. J Am Soc Exp Neuro Ther 4: 12-17.

Tortoriello J, Ortega A 1993. Sedative effect of galphimine B, a Nor-seco-triterpenoid from Galphimia galuca. Planta Med 59: 398-400.

Woodson RE, Youngken HW, Schlittler E, Schineider JA 1957. Rauwolfia: botany, pharmacognosy, chemistry \& pharmacology. New York: Littler, Brown and Company. 